\title{
Solusi Penyelesaian Persamaan Laplace dengan Menggunakan Metode Random Walk
}

Gapar1), Yudha Arman'1), Apriansyah²)

\author{
1)Program Studi Fisika Jurusan Fisika Universitas Tanjungpura \\ 2) Program Studi Ilmu Kelautan Jurusan Ilmu Kelautan Universitas Tanjungpura \\ Jl. Prof. Dr. H. Hadari Nawawi Pontianak \\ *Email : yudhaarman@gmail.com
}

\begin{abstract}
Abstrak
Telah dilakukan penentuan distribusi suhu dalam keadaan tunak pada sebuah plat dua dimensi menggunakan metode Random Walk. Setiap sisi plat dikondisikan bersuhu $100^{\circ} \mathrm{C}$ dan $0^{\circ} \mathrm{C}$ dalam 4(empat) konfigurasi dan dalam keadaan steady. Persamaan Laplace yang mengkarakterisasi permasalahan ini dihampiri dengan melibatkan sejumlah walker pada setiap titik perhitungan untuk kemudian secara acak disebar menuju ke setiap sisi plat. Hasil yang diperoleh untuk setiap kondisi plat menunjukkan kesalahan relatif terhadap solusi analitik secara rata-rata adalah 5,17\%. Nilai kesalahan tersebut diperoleh dengan menggunakan 2000 walker. Penelitian ini juga mendapatkan bahwa akurasi hampiran ditentukan oleh banyaknya walker yang digunakan. Secara umum, semakin banyak jumlah walker yang digunakan maka akurasi hampiran akan semakin baik.
\end{abstract}

Kata Kunci : Persamaan Laplace, Distibusi Suhu Keadaan Steady, Random Walk, Walker

\section{Latar Belakang}

Suhu adalah besaran yang menyatakan panas dan dingin suatu bahan. Kajian fenomena laju distribusi suhu telah banyak dilakukan dengan menerapkan model konvensional yaitu model analitik dan numerik, model yang digunakan untuk memecahkan langsung persamaan Laplace yang merupakan persamaan pengatur laju distribusi suhu.

Perkembangan teknologi dewasa ini terutama dalam bidang komputasi menyebabkan ditemukannya beberapa metode yang dapat digunakan untuk menyelesaikan permasalahan distribusi suhu. Tahun 2008 Apriansyah menerapkan metode Cellular Automata, tahun 2011 Supandiyono menggunakan metode beda hingga dan tahun 2012 Sumarji menggunakan metode elemen hingga. Pada penelitian ini akan dilakukan pemecahan masalah distribusi suhu dengan menggunakan metode random walk.

Metode random walk didasarkan pada peluang pergerakan acak partikel pada ruang dan peluang untuk menggandakan ataupun menghilangkan dirinya (Anderson, 2002). Pemilihan metode random walk didasarkan pada kesederhanaan operasi matematis yang digunakan. Solusinya akan dibandingkan dengan hasil dari perhitungan analitik.

Penelitian ini bertujuan untuk menerapkan persamaan Laplace dan metode random walk untuk menentukan distribusi suhu dalam keadaan jenuh pada sebuah plat, serta membandingkan hasil perhitungan distribusi suhu dari metode random walk dengan solusi analitik. Hasil penelitian ini diharapkan dapat memberikan gambaran visual terhadap penyelesaian persamaan Laplace

\section{Metodologi}

\subsection{Persamaan Laplace}

Persamaan gelombang dapat dituliskan sebagai berikut :

$$
\nabla^{2} \psi=\frac{1}{v^{2}} \frac{\partial^{2} \psi}{\partial t^{2}}
$$

Dengan $\psi$ perpindahan atau simpangan. Jika $\psi$ tak bergantung waktu, maka persamaan (1) menjadi

$$
\nabla^{2} \psi=0
$$

Persamaan (2) ini dikenal sebagai persamaan Laplace

Persamaan Laplace sering ditemui dalam fisika, sebagai contoh dalam medan elektrostatik, dimana persamaan Laplace mendeskripsikan distribusi potensial listrik dalam keadaan tunak (steady state) dalam ruang tanpa muatan.

Persamaan yang mirip dengan persamaan (1) ditemukan dalam termodinamika dalam bentuk;

$$
\nabla^{2} T=\frac{1}{D} \frac{\partial T}{\partial t}
$$

Dalam hal ini $\mathrm{T}$ merupakan fungsi yang mendeskripsikan distribusi suhu $\mathrm{T}$ di dalam ruang sebagai fungsi dari ruang dan waktu. D adalah konstanta difusi dan persamaan ini dikenal dengan persamaan difusi. Bila T tidak 
bergantung waktu, persamaan (3) menjadi persamaan Laplace

$$
\nabla^{2} T=0
$$

Dalam sistem koordinat kartesian, persamaan (4) dapat ditulis sebagai;

$$
\frac{\partial^{2} T}{\partial x^{2}}+\frac{\partial^{2} T}{\partial y^{2}}+\frac{\partial^{2} T}{\partial z^{2}}=0
$$

Persamaan (4) juga berlaku untuk kasus distribusi suhu di dalam lempeng yang terdapat sumber panas.

$\nabla^{2}$ ditulis dalam koordinat kartesian karena domain permasalahan berbentuk persegi panjang. Selain itu, permasalahan yang ditinjau dibatasi berdimensi dua.

Secara analitik, untuk menyelesaikan persamaan (4) digunakan teknik separasi variabel. Dengan menganggap bahwa :

$$
T(x, y)=X(x) Y(y)
$$

adalah hasil perkalian dari dua fungsi saling bebas, yaitu $\mathrm{X}$ adalah fungsi dengan peubah bebas $\mathrm{x}$ sementara $\mathrm{Y}$ adalah fungsi dengan peubah bebas y, substitusi persamaan (6) ke persamaan (5) menghasilkan:

$$
\begin{aligned}
& \frac{\partial^{2} X Y}{\partial x^{2}}+\frac{\partial^{2} X Y}{\partial y^{2}}=0 \\
& Y \frac{\partial^{2} X}{\partial x^{2}}+X \frac{\partial^{2} Y}{\partial y^{2}}=0
\end{aligned}
$$

Hasil pembagian persamaan (8) dengan perkalian dua fungsi tersebut, $\mathrm{XY}$, diperoleh :

$$
\begin{aligned}
& \frac{1}{X} \frac{\partial^{2} X}{\partial x^{2}}+\frac{1}{Y} \frac{\partial^{2} Y}{\partial y^{2}}=0 \\
& \frac{1}{X} \frac{\partial^{2} X}{\partial x^{2}}=-\frac{1}{Y} \frac{\partial^{2} Y}{\partial y^{2}}
\end{aligned}
$$

Karena ruas kanan dan kiri tidak dapat berubah bila $\mathrm{x}$ dan $\mathrm{y}$ berubah, maka ke dua ruas harus sama dengan sebuah konstanta $\left(-k^{2}\right)$. Persamaan (10) kemudian dapat sdituliskan sebagai :

$$
\begin{aligned}
& \frac{1}{X} \frac{\partial^{2} X}{\partial x^{2}}=-\frac{1}{Y} \frac{\partial^{2} Y}{\partial y^{2}}=\text { konst }=-k^{2}, \\
& k \geq 0 \\
& X^{\prime \prime}=-k^{2} X \text { dan } Y^{\prime \prime}=k^{2} Y
\end{aligned}
$$

Konstanta $\left(k^{2}\right)$ disebut konstanta separasi. Solusi dari persamaan (12) adalah:

$$
\begin{aligned}
& X=\left\{\begin{array}{l}
\sin k x \\
\cos k x
\end{array}\right. \\
& Y=\left\{\begin{array}{l}
e^{k y} \\
e^{-k y}
\end{array}\right.
\end{aligned}
$$

Hasil substitusi persamaan (13) dan persamaan (14) ke persamaan (12) menghasilkan :

$$
T=X Y=\left\{\begin{array}{c}
A e^{k y} \sin k x \\
B e^{-k y} \sin k x \\
C e^{k y} \cos k x \\
D e^{k y} \cos k x
\end{array}\right.
$$

Jika konstanta $\left(-k^{2}\right)$, diganti dengan $\left(+k^{2}\right)$. maka persamaan (10) kemudian ditulis sebagai:

$$
\begin{aligned}
& \frac{1}{X} \frac{\partial^{2} X}{\partial x^{2}}=-\frac{1}{Y} \frac{\partial^{2} Y}{\partial y^{2}}=\text { konst }=+k^{2}, \\
& k \geq 0 \\
& X^{\prime \prime}=k^{2} X \quad \text { dan } \quad Y^{\prime \prime}=-k^{2} Y
\end{aligned}
$$

Konstanta $\left(k^{2}\right)$ disebut konstanta separasi. Solusi dari persamaan (17) dituliskan sebagai:

$$
\begin{aligned}
& X=\left\{\begin{array}{l}
e^{k x} \\
e^{-k x}
\end{array}\right. \\
& Y=\left\{\begin{array}{l}
\sin k y \\
\cos k y
\end{array}\right.
\end{aligned}
$$

Substitusi persamaan (18) dan persamaan (19) ke persamaan (10) menghasilkan

$$
T=\left\{\begin{array}{c}
A e^{k x} \sin k y \\
B e^{-k x} \sin k y \\
C e^{k x} \cos k y \\
D e^{-k x} \cos k y
\end{array}\right.
$$


Kondisi plat yang akan disimulasikan diperlihatkan pada Gambar (1)

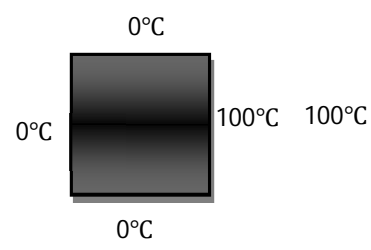

(a)

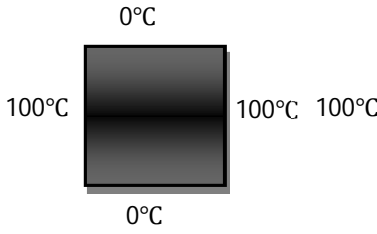

(c)

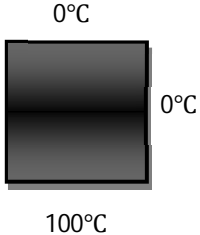

(b)

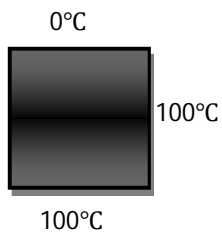

(d)
Gambar 1. Kondisi plat yang diamati

\subsection{Metode Random walk}

Metode paling sederhana dalam menyelesaikan suatu permasalahan tanpa harus melibatkan banyak operasi matematika dan struktur data adalah memanfaatkan kejadian acak (random walk). Metode ini menghasilkan sebuah penyelesaian dengan mencoba-coba serta memanfaatkan bilangan acak (Basuki, dkk, 2004).

Random walk pertama kali diperkenalkan oleh Karl Pearson pada tahun 1905. random walk merupakan formalisasi matematika dari sebuah lintasan yang terdiri dari langkahlangkah secara acak yang berurutan. Misalnya, lintasan yang dilewati oleh suatu molekul dalam suatu zat cair atau gas. Random walk telah digunakan di berbagai bidang misalnya Ekologi, Sikologi, Ilmu Komputer, Fisika, Kimia dan biologi (Pearson, 1905).

Berdasarkan pendekatan dalam memproses data, maka dikenal dua tipe pendekatan, yaitu tipe floating random walk merupakan model yang mengizinkan jumlah walker selalu berubah dalam simulasi. Tipe ini dapat menyebabkan simulasi tidak stabil karena dalam simulasi bisa timbul sedikit walker (kebanyakan hilang dalam proses) sehingga tipe ini spesifik untuk satu aplikasi. Sedangkan tipe fixed random walk merupakan model yang menggunakan jumlah walker selalu tetap atau konstan. Jumlah akan walker bertahan sampai akhir simulasi sehingga cocok untuk beberapa aplikasi perhitungan. Tipe ini lebih baik dari pada tipe floating random walk (Ketut, 2009).

\subsection{Penerapan Metode Random Walk Pada Persamaan Laplace}

Solusi persamaan Laplace dua dimensi pada titik $(\mathrm{x}, \mathrm{y})$ dituliskan dengan persamaan sebagai berikut;

$$
T(x, y)=\frac{1}{4} \sum_{i=1}^{4} T(i)
$$

dengan $T(i)$ adalah nilai suhu terdekatnya.

Algoritma metode random walk untuk menghampiri solusi persamaan Laplace dapat dituliskan sebagai berikut:

1. Dimulai dari titik $(x, y)$ dimana nilai suhu yang diinginkan. Walker kemudian dipindahkan dalam arah acak.

2. Selanjutnya walker dijalankan hingga mencapai permukaan. Suhu permukaan yang dicapai $T_{b}$ kemudian disimpan sebagai suhu pada batas (i)

3. Langkah 1 dan 2 diulang setiap waktu dan suhu yang didapat kemudian dijumlahkan pada permukaan setiap waktu.

4. Nilai dari suhu pada titik $(x, y)$ dihasilkan oleh:

$$
T(x, y)=\frac{1}{n} \sum_{i=1}^{n} T_{b}(i)
$$

Dalam bentuk lain, persamaan (22) dapat ditulis sebagai :

$T(x, y)=\frac{T(x, y) 1+T(x, y) 2+\cdots+T(x, y) n}{N}$

dimana n jumlah walker.

Ilustrasi pergerakan walker dapat dilihat pada Gambar (2).

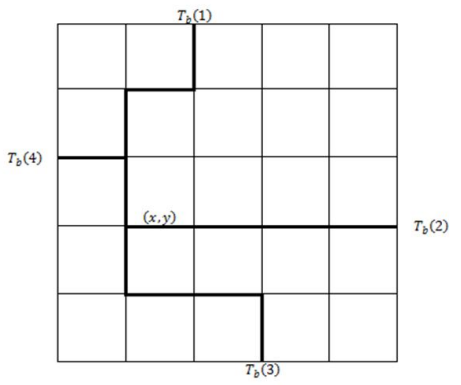

Gambar 2. Contoh pergerakan walker

Pada titik $(\mathrm{x}, \mathrm{y})$, walker yang digunakan kemudian diarahkan secara acak untuk bergerak ke titik grid terdekat. Setiap satu titik grid yang ditempuh oleh walker memerlukan satu proses perhitungan. Jika grid yang didatangi oleh walker bukan merupakan daerah batas domain, walker akan terus bergerak secara acak ke grid berikutnya. Apabila grid tersebut merupakan wilayah batas domain, walker akan berhenti 
untuk kemudian membawa informasi nilai syarat batas pada titik tersebut.

\section{Hasil dan Pembahasan \\ 3.1 Kondisi I}

Hasil plot distribusi suhu pada plat untuk kondisi I diberikan oleh Gambar (3)

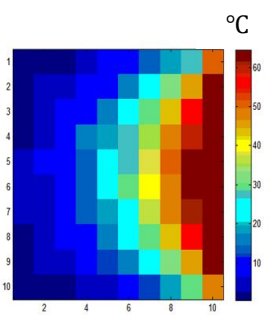

(a)

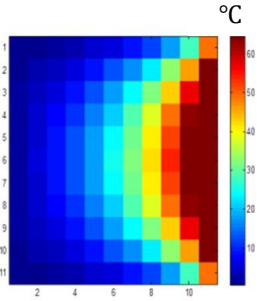

(b)
Gambar 3. Hasil plot solusi distribusi suhu

kondisi I secara (a) analitik dan (b) numerik

Pada Gambar 3a terlihat suhu yang lebih tinggi berada di daerah sebelah kanan plat dengan berbagai variasi gradasi suhu. Hal ini dimungkinkan karena daerah ini dapat dianggap merupakan sumber kalor bagi daerah sekitarnya. Gradasi suhu terlihat sedikit lebih landai di bagian tengah domain permasalahan namun cukup curam di daerah atas dan bawah. Hal ini disebabkan kontribusi suhu rendah di batas domain atas dan bawah yang menyebabkan kesetimbangan kalor lebih cenderung menempatkan daerah yang bersuhu lebih tinggi berada di daerah tengah. Gradasi semakin melandai ke arah kiri domain permasalahan dimana suhu plat dibuat bernilai $0^{\circ} \mathrm{C}$.

Hasil plot distribusi suhu pada plat untuk kasus 1 diperlihatkan pada Gambar 3b. Selisih relatif rms antara hasil simulasi numerik dengan simulasi analitik sebesar 5,44\%. Selisih ini didapat menggunakan walker berjumlah 2000 . Jumlah walker ini merupakan hasil trial and error. Telah dicoba sebelumnya jumlah walker yang lebih kecil dari jumlah walker tersebut di atas, namun hasil yang diperoleh masih menunjukkan nilai di bawah kualifikasi yang dibutuhkan. Kondisi ini juga sesuai dengan kondisi persamaan (23) dimana pendekatan random walk akan bernilai semakin baik jika jumlah walker diperbesar. Keterbatasan perangkat lunak yang digunakan serta keterbatasan perangkat keras membuat jumlah walker yang digunakan hanya sebesar 2000 .

\subsection{Kondisi II}

Hasil plot solusi persamaan Laplace untuk kondisi II menggunakan metode analitik dan numerik Random Walk diperlihatkan pada Gambar (4)

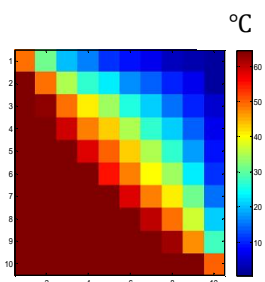

(a)

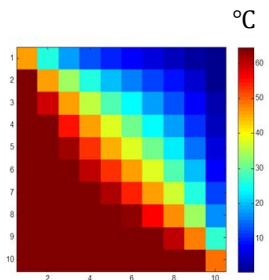

(b)
Gambar 4. Hasil plot solusi distribusi suhu kondisi II secara (a) analitik dan (b) numerik

Dari gambar terlihat gradasi suhu seragam berarah diagonal plat yang ditinjau. Kondisi ini berbeda dengan yang ditunjukkan pada kondisi I dimana gradasi suhu besar hanya di bagian tepi plat. Hal ini disebabkan pada kondisi II dua sisi plat yang bersinggungan diberi suhu tinggi sementara dua sisi plat yang lain dikondisikan bersuhu $0^{\circ} \mathrm{C}$. Suhu tinggi pada dua sisi plat yang bersinggungan merupakan sumber kalor bagi bagian dalam plat. Kondisi aliran ini merupakan kondisi yang sudah dalam keadaan jenuh.

Hasil distribusi suhu menggunakan metode random walk menunjukkan pola yang sama. Selisih relatif rms terhadap solusi analitik sebesar 3,37\% menggunakan walker berjumlah 2000. Jumlah walker ini, sama seperti pada kondisi I, diperoleh melalui trial and error. Keterbatasan perangkat lunak dan perangkat keras yang digunakan merupakan pertimbangan utama bagi jumlah walker ini. Karena hanya menghitung nilai rata-rata dari pengumpulan nilai walker, metode ini mengharuskan jumlah walker besar untuk mencapai kualifikasi yang diinginkan.

\subsection{Kondisi III}

Hasil plot solusi persamaan Laplace untuk kondisi III menggunakan metode analitik dan numerik Random Walk diperlihatkan pada Gambar (5)

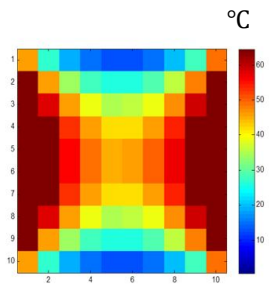

(a)

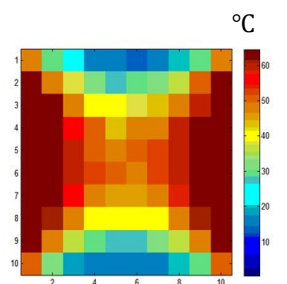

(b)
Gambar 5. Hasil plot solusi distribusi suhu kondisi III secara (a) analitik dan (b) numerik 
Dari gambar terlihat gradasi suhu lebih landai pada bagian tengah dari plat. Sisi atas dan bawah plat masih bersuhu rendah karena pada keadaan jenuh tercapai, jumlah kalor yang diperlukan untuk membuat bagain ini bersuhu lebih tinggi lagi masih kurang walaupun kontribusi suhu tinggi didapatkan dari dua sisi plat.

Solusi numerik menggunakan metode random walk juga menampilkan hasil yang serupa. Secara kualitatif, solusi numerik telah mampu menghasilkan solusi yang baik jika dibandingkan dengan hasil solusi analitiknya. Secara kuantitatif, diperoleh selisih relatif rms sebesar 7\%. Jika dibandingkan dengan kondisi sebelumnya, nilai ini lebih besar. Hal ini disebabkan karena proses pembulatan hasil perhitungan nilai rata-rata suhu yang dibawa oleh walker. Pembulatan ini akan berpengaruh signifikan karena nilai suhu yang digunakan pada batas domain cukup besar.

\subsection{Kondisi IV}

Hasil plot solusi persamaan Laplace untuk kondisi IV menggunakan metode analitik dan numerik Random Walk diperlihatkan pada Gambar (6)

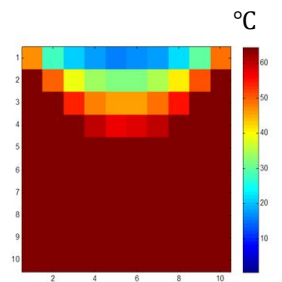

(a)

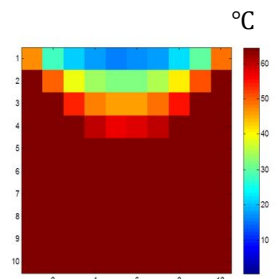

(b)
Gambar 6. Hasil plot solusi distribusi suhu kondisi IV secara (a) analitik dan (b) numerik.

Pada gambar terlihat gradasi suhu lebih tinggi berada di bagian bawah plat dengan berbagai gradasi temperatur. Gradai temperatur terlihat lebih landai di bagian tengah plat namun cukup curam di bagian kanan dan kiri plat. Hal ini disebabkan temperatur di bagian atas plat bernilai $0^{\circ} \mathrm{C}$.

Solusi numerik menggunakan metode random walk juga menampilkan hasil yang serupa. Secara kualitatif, solusi numerik telah mampu menghasilkan solusi yang baik jika dibandingkan dengan hasil solusi analitiknya. Secara kuantitatif, diperoleh selisih relatif rms sebesar 4,87\%. Selisih ini didapat menggunakan walker berjumlah 2000. Jumlah walker ini merupakan hasil trial and error.
Selisih kondisi I dengan walker bervariasi telah dicoba dan didapat hasil sesuai dengan tabel di bawah ini.

\begin{tabular}{cc}
\hline Walker & Selisih rms \\
\hline 100 & $\mathbf{3 7 , 3 7}$ \\
$\mathbf{5 0 0}$ & $\mathbf{1 3 , 6 1}$ \\
$\mathbf{1 0 0 0}$ & $\mathbf{9 , 4 4}$ \\
$\mathbf{1 5 0 0}$ & $\mathbf{8 , 7 1}$ \\
$\mathbf{2 0 0 0}$ & $\mathbf{5 , 4 4}$ \\
\hline
\end{tabular}

Tabel 1. Walker bervariasi pada kondisi I

Dari tabel terlihat peningkatan akurasi seiring bertambah jumlah walker yang digunakan. Peningkatan itu cukup signifikan apabila penambahan jumlah walker berkelipatan besar.

\section{Kesimpulan}

Dari penelitian ini dapat disimpulkan bahwa untuk kasus distribusi suhu dalam keadaan tunak pada sebuah plat sebagai berikut: Kondisi I dengan rms sebesar 5,44\%, kondisi II dengan rms sebesar 3,37\%, kondisi III dengan rms sebesar 7,00\%, kondisi IV dengan rms sebesar 4,87\%. Metode Random Walk dapat menghampiri solusi analitik dengan baik.

\section{Daftar Pustaka}

Anderson, J.B., 2002, Diffusion and Gren's Function Quantum Monte Carlo Methods, John von Neuman Institute for computing, Jülich, NIC Series, Vol. 10, ISBN 3-00-009057-6, pp. 25-50, 2002.

Apriansyah, 2008, Simulasi Distribusi Suhu Keadaan Tunak (steady state) Pada Lempeng 2 Dimensi Dengan Menggunakan Metode Cellular Automata, Jurusan Fisika FMIPA UNTAN, Pontianak (skripsi S1).

Basuki, A., Santoso, T. B., dan Huda, M., 2004, Modelling dan Simulasi, IPTAQ Mulia Media; Jakarta.

Ketut, G., 2009, Monte Carlo Method, http:/ / www.gagus-ketut.blogspot.com/ / 2009/ 05/ metode-monte-carlo.html, Februari 2012).

Sumarji, 2012, Simulasi Distribusi Suhu Pada Plat Dua Dimensi Menggunakan Metode Elemen Hingga (Finite Elemen Method), Jurusan Fisika FMIPA UNTAN, Pontianak (skripsi S1).

Pearson, K., 1905, The problem of the Random Walk, Nature, 72, 294.

Supardiyono, 2011, Analisis Distribusi Pada Pelat Dua Dimensi Dengan Menggunakan Metode Beda Hingga, JPFA, Vol.1, No.2 